\title{
Make an Intranet network to build a modern supermarkets chains in Kalar city to improve sales and performance via main controller and multi branches
}

\author{
Abbas Mohamed Salah
}

\section{Article Info}

Received: April, 2019

Revised:April,2019

Accepted:April,2019

\section{Keywords}

supermarket, e-commerce, Intranet, onlineShopping, IT management.

\section{Corresponding Author}

studnet4ever@gmail.com

\begin{abstract}
The chain supermarket in the domestic have been grown up. Because of the proffesional staff, the quick development of enterprise, the information technology has been elevated to a new step.

But, the lack of alignment between strategy and business goals is the source of the problems. So, business areas should effectively managing those projects before the IT area. Then, an efficient IT management is necessary, so that IT projects should be show up in relation with strategic alignment view and the achievement of organization goals.

The aim of this work is to build an intranet network to connect a chain of supermarkets for the city by using the newest technology that simplify management information system. The work helps owners and managers gather information relating to their company. Meanwhile, right now in the city the supermerks manually working or at least the network is missing in the business field.

Therefore, computerized management information systems is necessary to help much more convenient for manger to control and monitor all items in the branches. So, the supermarkets later on, much faster ,easier and powerful. Finally, it can helps to save time, money, and it makes the company become more accurate.
\end{abstract}

\section{Introduction}

Business as the link between production and consumption, with information technology, various businesses not only progress themselves' competiteveness in market but also can conduct production and stimulate consumption. So, systemic integration levels are necessary for business organizations. The infromation construction has been current tend which large businesses change the way of management in order to survive. This show that its IT areas should develop a successful strategies and enough competences to face IT demand[1-4].
Recently, depend on the literature[5], the chain supermarket in the domestic have been grown up. Because of the proffesional staff, the quick development of enterprise, the information technology has been elevated to a new step.

Meanwhile, supermarket as a missed-industry, who can decrease production cost by the greatest way and cut down the cost of procurement, the distribution and the inventory management, who can entice more customers[8]. 
Therefore, some researchers [6,7] showed that the lack of alignment between strategy and business goals is the source of the problem. So, business areas should effectively managing those projects before IT area. Then, an efficient IT management is necessary, so that IT projects should be show up in relation with strategic alignment view and the achievement of organization goals . Finally, business leaders should know the key factor is IT demands management wholesome viewing [9].

The aim of this work is to build an intranet network to connect a chain of supermarkets for the city by using the newest technology that simplify management information system. The work helps owners and managers gather information relating to their company. Meanwhile, right now in the city the supermerks manually working or at least the network is missing in the business field.

Therefore, computerized management information systems is necessary to help much more convenient for manger to control and monitor all items in the branches. So, the supermarkets later on, much faster, easier and powerful. Finally, it can helps to save time, money, and it makes the company become more accurate.

This article is divided into 6 sections. Section 1 presents Introduction to business. Section 2 describes the Project organization. Section 3 describes the Managerial process plans . Section 4 shows the Technical process plan. Section 5 presents the Project budget. Section 6 the Approval of the project steps. Finally, Section 7 presents Conclusion and future services .

\section{The project organization}

In this section, we begin with Deliverable, Definitions and Acronyms of the hardware and software of the project for main and its branches as listed in the table 2.1

\begin{tabular}{|c|c|c|c|}
\hline Deliverable & Recipients & $\begin{array}{c}\text { Delivery } \\
\text { Date }\end{array}$ & $\begin{array}{l}\text { Delivery } \\
\text { Method }\end{array}$ \\
\hline AA & $\begin{array}{c}\text { All } \\
\text { branches }\end{array}$ & $\begin{array}{l}1 \text { Jan } \\
2018\end{array}$ & NT \\
\hline $\mathrm{AB}$ & $\begin{array}{c}\text { All } \\
\text { branches }\end{array}$ & $\begin{array}{c}1 \mathrm{Feb} \\
2018\end{array}$ & NT \\
\hline $\mathrm{AC}$ & $\begin{array}{c}\text { All } \\
\text { branches }\end{array}$ & $\begin{array}{c}1 \mathrm{Mar} \\
2018\end{array}$ & NT \\
\hline $\mathrm{AD}$ & Main & $\begin{array}{l}1 \mathrm{Apr} \\
2018\end{array}$ & NT \\
\hline $\mathrm{AE}$ & $\begin{array}{l}\text { Main and } \\
\text { All } \\
\text { branches }\end{array}$ & $\begin{array}{c}9 \text { may } \\
2018\end{array}$ & $\mathrm{TE}$ \\
\hline
\end{tabular}

Table 2.1 HW \& SW defintion parts

AA: all hardware components that's need for each branch of this project .

AB: all software components that's need for each branch of this project .

AC: all staffs.

AD: server, sector and hub.

NT: company staff that's currently available and other necessary staffs.

TE: testing plan, testing report and testing result.

The project organization consist of the three parts, the first is: External interfaces. According to structure of this project, it's consist of different staffs like lawyer ,IT management, stakeholder, employee and other staffs, finance, products, communicating and tracking of items between the main and branches, and relationship with external companies . these are the boundaries of this project as shown in the (Char 3.1).

The second part is: internal structure, the project is continuously selling Items to their customers via the 12 branches of supermarket with helping IT managers in main and each branch and other employees and staffs, also monitoring and tracking via $\mathrm{DB}$ to filling items that will be finishing time by time. Roles and Responsibilities, is the third part, the staffs as in the following listed are the major project teams have roles and their responsibility:

- Project Manager (IT manager): responsible for building the stated project objectives.

- Software Engineer: who applies all principles that related to software system. 
- Technical Leader: managing all technical issues.

- Software Leader: explaining and responsible for all software issues and monitoring the software development team.

- Hardware Leader: solving all hardware issues and monitoring the network and

hardware development team.

- Systems Engineer: responsible of how the project should be designed and managed over the life cycle of the project.

- Programmer: Is responsible to implement the software system.

- Database Designer: Is responsible for design the structure of data for the system.

- Hardware Engineer: Is responsible for installing and configuring hardware components.

- Others staffs : which they have experience with this type of project for solving any expected or unexpected issues that during or after the project occur.

And some other staffs that don't have relationship with the project team but they are linked to the company (finance manager, electrical Eng., drivers, main director, customers and auditors)

\section{Managerial process plan}

Project startup is a very short phase of the project management cycle. It is a transition step between project organization and execution. While it is a short step, important events occur. The section consist of the Start-up, Work, Risk Management, Issues resolution, Close-out plan as follow:

\section{Start-up plans}

\section{Staffing plan}

Developing a staffing plan for the project involves selecting, assembling, numbers and skill levels in each project phase and assigning work to a project team with the appropriate skill sets to meet the project deliverables identified during the project initiation stage as shown in table 3.1.

\section{Project staff training}

This section is specify the training for staff of the company that's necessary before the project finish, so that this training enable the staffs for using hardware and software components easily that needed during the availability of them inside the company such as (windows, database , antivirus ,barcode reader ,pc and etc.), the following table shows types of training, numbers of personnel, training method and location:-

\section{Resource Acquisition}

We specified the plan for acquiring the resources (hardware and software equipment) and assets, in addition to personnel, needed to successfully complete the project as in the table 3.1.C.

\section{Work plan}

After the project has been defined and the project team has been appointed, the work go into the work plan phase in the project plan life cycle. This phase is often the most challenging phase for the project manager, as you need to make an educated guess about the staff, resources, and equipment needed to complete your project. Also the mananger need to make plan communications and procurement activities, as well as contract any third-party suppliers. The basic processes of work plan are listed in the some sections as shown in the table 3.2 :-

\section{Data control plan}

All these primary and secondary data and information company will kept as a secondary copy for archive in the security location (hard disk drive ,blank DVD or drop-box server (this is security storage internet location) these data and information are :

-All daily tracking data.

-adding, deleting or changing information.

-privacy data.

-selling and buying daily products.

\section{Requirement control plan}

The project will have weekly and monthly reports for status for daily project actions like(advantages , company progress , people requirement ,staff proposal problem and defects). If any changes requested in the (requirements, the quality, schedule, budget, resource, and risk factors) will be affected, therefore the project manager plan, estimates, and commitments should be reviewed to accept the changes at that time the agreement proposal should be updated. 


\section{Schedule Control Plan}

As we explained in the Requirement control plan according to this company we can measure the progress of our company via reports (weekly and monthly),for this the manager can know via the weekly reports can be used to compare actual schedule performance to planned performance and to implement corrective action when actual performance deviates from planned or required performance. The project team will evaluate progress weekly and as milestones occur. Progress will be measured against projected project timeline.

We use Gantt chart (Char 3.2.C) for the project schedule to see the actual and planned performance. As a sample showed blew illustrate the actual and planned performance

According to Gantt chart, if actual performance is deviated from past estimated we have two ways to solve this:

1-if we have long time period we try to solve by finding the causes.

2-else we will notice the company about the state and it's causes to do meeting and fixing this problem or the other as soon as possible to attempt to be of the least impact.

\section{Budget Control Plan}

Budget expenditures will correspond to approved budget plan. Review of expenditures will occur according to weekly report and requirements that will come from(customer ,staff ,progress, faults and updates, and cost estimates for hardware components, software components, and staff salary will be compared to the actual cost that estimated for the entire project also our budget for this company generally can show visually how to reserve for main activity to continuity going company as in table :

\section{Risk Management Plan}

Plan for identifying, analyzing, prioritizing, and controlling project risks. Via weekly and monthly reports we can identify and prioritize any defects and risks, The project will assess risks, communicate risks to participants, monitor risks, identify and implement resolutions as appropriate. Risk management is the responsible to notice project manager via typical
Communication Mechanism (phone, email ,meeting..) to allocate budget and resolve risks as soon as possible .

\section{Issues resolution}

Problems, issues, and action items that arise on the project will be documented in daily program notes. Project team will review and develop a plan for resolution. Some problem or risk is dangerous need emergency plan because of not rise any more loses of data or risk technique like burning.

\section{Project close-out plan}

To achieve an orderly closeout of the project the following will occur:

1.) archiving of project materials

All project documents will be archived on CD/DVD.

2.) recording of metrics

Project metrics data will be collected, reported and archived on CD/DVD.

3.) holding a project retrospective

Participants will be asked to complete a post project survey for feedback.

Participants will be asked to participate in a final group session for recognition and celebration.

4.) preparation of a final report to include lessons learned

A final report will be compiled. Lessons learned from the project will be discussed.

5.) analysis of project objectives achieved

Project objectives will be reviewed and analyzed for completion.

\section{Technical Process Plans}

Project technical planning is thinking of what project activity we will do before we do it. Planning mechanisms have served project managers well in planning for their projects. This phase break down into four sub sections as below explained.

\section{Process model}

The business process model, provides a quick introduction to some Unified Modeling Language (UML) concepts and how they are applied in Enterprise Architect's Business Process Model as shown in UML 4.1. 


\section{Methods, Tools, and Techniques}

we will buy PCs for all branches and special PC for main by the following properties as in table 4.2:

And also we will installing the network by the following design for company main and its branches as in char 4.2:

Each branch's network will be connected to the intranet and managed by Zanyar Company that's available in the Kalar. A server is placed at the main branch. This server is used to hold the Database System

of the company. The server operating system will be Windows Server 2008 and operating system of other PCs will be Win7 32 bit professional. and other all branches use the database system through a private IP that reserved by Zanyar Company.

The following tools and languages will be used to design the database system:

- Languages and scripts: HTML, PHP, JavaScript, CSS, AJAX

- DBMS: MySQL

- Compiler: WAMP 3.0 (includes: Apache, PHP, MySQL, phpMyAdmin).

\section{Documentation Plan}

Whole documentations of project will deliverable as following table 4.3.

\section{Project Dependencies and Closure Requirements}

The project is managed all parts by itself except intranet managed by Zanyar Company and it is not dependent on any other projects or company . By 12 Nov 2018, when all the hardware, software and documentation deliverables have been finished, reviewed and accepted, the project will be finished.

\section{Project budget}

Project budget is a financial and personnel disposal limits that are needed for the project implementation. Its creating helps to define the maximal of money, work costs and resources necessary for the certain project. The project budget is approved in a project order. The operations for the budget preparation are therefore not completed. The changes, which are not corresponding to the planned budget, can occur during the project. In this phase, we have estimated the total cost of the project. Our estimate for this work is $156935 \$$ as detailed in the table 5.1.

\section{Approval}

The flowchart below (fig 6.1) show the process of approval that review all (phase description, objectives, deliverables, completion status, issues and actions) that prepared by project teams and then it'll review by project team review if approved then send to project manager for last review and then transmit to implement but if not accept by project manager resend to project approval team review. And before send to project manager if not accepted by approval team review it must be update and conduct review as necessary then if accept by same team send to project manager else this loop is continue till accept or change some main part or last action cancel the project .

\section{Conclusion and future work Conclusion}

In the work is to build an intranet network to connect a chain of supermarkets for the city by using the newest technology that simplify management information system. The work helps business owners and managers gather information relating to their company. Meanwhile, right now in the city the supermerks manually working or at least the network is missing in the business field.

Therefore, Computerized management information systems is necessary to help much more convenient for manger to control and monitor all items in the branches. So, the supermarkets later on, much faster ,easier and powerful. Finally, it can helps to save time, money, and it makes the company become more accurate.

\section{Future work}

1- increase the scale of the branches in all of the Kurdistan cities

2- growing the availability of more items like as, vehicle parts, electrician tools and etc.

3- $\quad$ Make a website for the project which offers the services of ordering online and then picking up your groceries or any products in 
store and then during 30 minutes they are reach their homes.

\section{References}

[1] "IT Demand Management Models in Organizations",6th International Conference on Information Communication and Management, Luis Palacios Quichíz and Sussy Bayona-Oré, 2016

[2]"A Survey of Warehousing Technology in Electronic Commerce Supermarket", IEEE Conferences, Li Fangmin, 2015

[3] "Technology Enabled Customer Relationship Management in Supermarket Industry in Nigeria", Olamade O. Owolabi, American Journal of Industrial and Business Management, Yusuff S. Adeleke, Kazeem Abubakar, 2013

[4] "A Framework of Smart Supermarket Based on the Internet of Things", Applied Mechanics and Materials, Y. G. Zhang and B. Shen, 2012

[5] "An empirical study of factors influencing customer satisfaction of Decathlon sports professional supermarket", International Conference on Computer Science and Service System (CSSS),Yarong Chen ; Yujing Guo, 2011

[6] "Vendor's risk evaluation of chain supermarket based on fuzzy analytic hierarchy process" , IEEE Conferences,Shifeng Xu ; Hong Xue2011
[7] "A solution for low cost and high performance smart home networking" , 2nd International Conference on Engineering and Industries (ICEI), Yikui Zhang ; Lili Ye ; Liwei Zhu ; Yisheng Lai, 2011

[8] "Research And Developmengt On The Chain Supermarket Management System Based On B/S", 2nd International Conference on Power Electronics and Intelligent Transportation System, lin Xu,Changjun Zhu, 2009.

[9] "Improving Supply Chain Effectiveness through Collaborative Project and Information Technology Governance", IEEEE, E. K. Chew, K. Niebecker,2010.

[10] "The business model comparative advantage and industry analysis of industrial products supermarket chains", International Conference on E-Business and E-Government,Sun Hongying , 2010.

[11] "Site selection of supermarket based on DEMATEL", IEEE Conferences , Sunmei Xie ; An Ren ; Ruixia Liu, 2009

[12]"Safeway builds connections with new intranet tools", https:/www.ragan.com/safewaybuilds-connections-with-new-intranet-tools, $19 / 1 / 2019$

[13]"The Best Way to Improve Internal Communication in Store Chains", https $/ /$ eee.do/how-to-improve-internalcommunication-in-store-chains/, 19/1/2019 


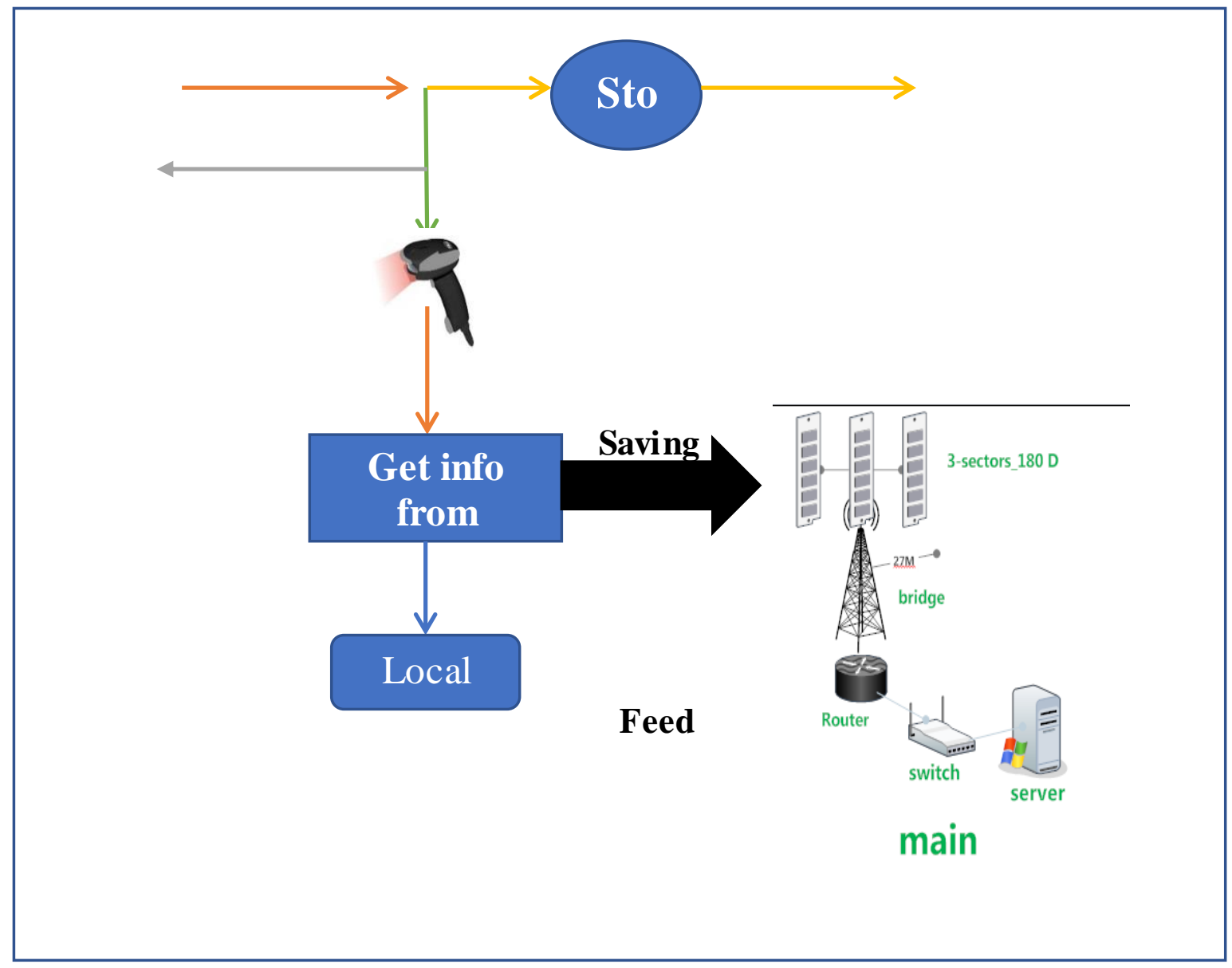

Char 3.1 Communicating and tracking between the main and its branches 
Table 3.1 Staffing plan

\begin{tabular}{|c|c|c|c|c|}
\hline Staff required Skill & $\begin{array}{l}\text { Staff } \\
\text { needed }\end{array}$ & Sources & Start and End date & Hourses \\
\hline Project Manager & 1 & I & 1 Jan to 9 may 018 & Full time \\
\hline Software engineer & 3 & $\mathrm{E}$ & 1 Jan to 9 may 018 & Full time \\
\hline Technical leader & 6 & $\mathrm{I}(2)+\mathrm{E}(4)$ & 1 Jan to 9 may 018 & Full time \\
\hline Hardware leader & 3 & $\mathrm{I}(1)+\mathrm{E}(2)$ & 1 Jan to 15 Feb 018 & 270 \\
\hline System engineer & 2 & $\mathrm{E}$ & 1 Jan to 9 may 018 & When need \\
\hline Programmer & 1 & $\mathrm{I}$ & 1 Jan to 1 match 018 & When need \\
\hline DB designer & 1 & $\mathrm{E}$ & 1 Match to 9 May & 420 \\
\hline Hardware engineer & 1 & I & 1 Jan to 1 match 018 & 90 \\
\hline Other staff & 3 & $\mathrm{E}$ & 1 Jan to 9 may 018 & When need \\
\hline
\end{tabular}

Table 3.1.B Staff training

\begin{tabular}{l|cc}
\multicolumn{1}{c}{ Methods } & No. of Staffes & Locations \\
\hline All IT components & 12 & All branches \\
Win 7 & 12 & All branches \\
Anti-virus & 12 & All branches branches \\
Some IT daily problem & 12 & All branches \\
Basic computer & 12 & 2
\end{tabular}


Table 3.1.C Necessary equipment of the project

\begin{tabular}{|c|c|c|c|}
\hline Resources & Equipment type & Quantity & Location \\
\hline Server & Hardware & 1 & Main \\
\hline Sector & Hardware & 3 & Main \\
\hline Barcode reader & Hardware & 12 & All branches \\
\hline Hub-3com & Hardware & 1 & Main \\
\hline Label-reader & Hardware & 12 & All branches \\
\hline $\mathrm{PC}$ & Hardware & 12 & All branches \\
\hline Cable full STP & Hardware & 2 cartoon & $\begin{array}{c}\text { All branches } \\
+ \text { main }\end{array}$ \\
\hline Bridge & Hardware & $50 \mathrm{M}$ & $\begin{array}{c}\text { All branches } \\
+ \text { main }\end{array}$ \\
\hline Router & Hardware & 13 & $\begin{array}{c}\text { All branches } \\
+ \text { main }\end{array}$ \\
\hline $\mathrm{Rj}-45$ & Hardware & 1000 items & $\begin{array}{c}\text { All branches } \\
+ \text { main }\end{array}$ \\
\hline Anti-virus AVG 2013 & Software & 12 & All branches \\
\hline MS-windows 7 & Software & 12 & All branches \\
\hline Windows server & Software & 1 & Main \\
\hline E-hard drive & Hardware & 1 & Main \\
\hline Database & Software & 1 & Main \\
\hline
\end{tabular}


Table 3.2 Work plan sections of the porject

\begin{tabular}{|c|c|}
\hline Millstones of project & Start AND End Day \\
\hline Project Analysis & 1 Jan to 22 Jan 018 \\
\hline Project Design & 23 Jan to 24 Feb 018 \\
\hline Project Coding & 25 Feb to 23 March 018 \\
\hline Project Installing & 24 March to 9 April 018 \\
\hline Project Testing & 10 April to 20 April 018 \\
\hline Project training & 21 April to 10 May 018 \\
\hline
\end{tabular}

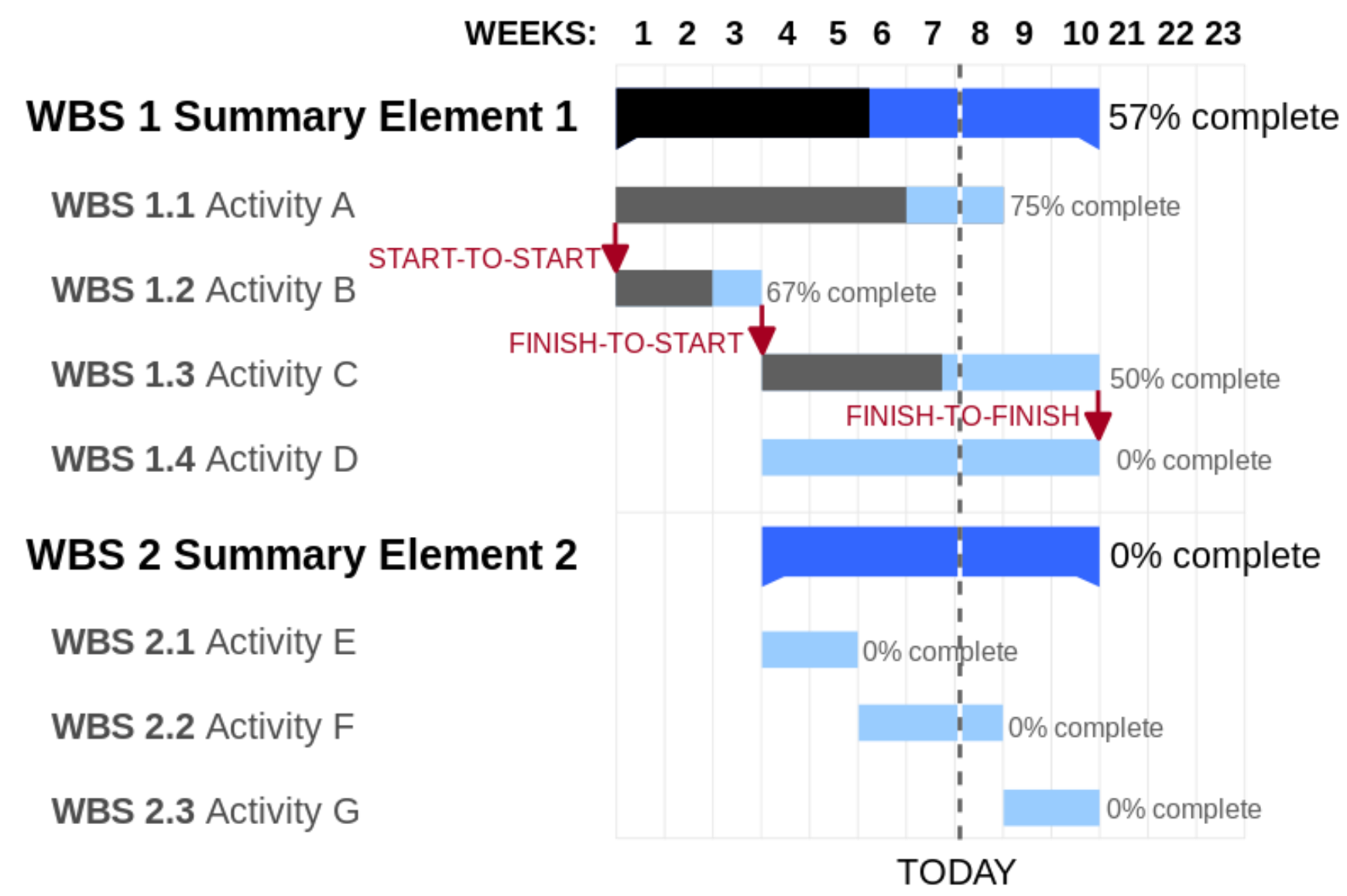

Char 3.2.C Schedule Control Plan 
Table 3.2.D. Budget Control Plan

\section{Objectives}

Staffing Costs

Professional/Staff Development

Substitute Teacher Time

Equipment/Software

Facilities/Transportation

Incentives:

\section{Description}

Any costs related to hiring staff to manage the expansion of the program.

Costs involved in training or teaching educators that will allow them to bettercontribute to your program. This includes teacher training courses, manuals or software.

Cost of substitute reimbursement if developing your program requires you or others working on the program to take time away from your clas sroom.

Cost of any lab equipment, office equipment, phone use, or computer software purchased to enhance the program.

Costs associated with disseminating information for or about your program. For instance, cost of any consumable office supplies, printing, photocopying, or costs incurred for the production and mailing of pamphlets, worksheets or brochures either needed for the program or to promote the program.

Cost as sociated with providing meals, snacks and other means of encouraging participants (prizes, $t$-shirts,etc.) during interactive portions of the program 
Communication, Tracking, and Reporting Plan

\begin{tabular}{|c|c|c|c|c|}
\hline Type of Communication & Communication Schedule & $\begin{array}{c}\text { Typical Communication } \\
\text { Mechanism }\end{array}$ & Who Initiates & Recipient \\
\hline Testing report & First two weeks & Team meeting & $\begin{array}{c}\text { Project } \\
\text { Manager, } \\
\text { technical } \\
\text { leader }\end{array}$ & Rashidya Manager \\
\hline Status Report & weekly & Phone & $\begin{array}{l}\text { Project } \\
\text { Manager }\end{array}$ & Team leader \\
\hline $\begin{array}{l}\text { Schedule and Effort } \\
\text { Tracking Report }\end{array}$ & Weekly & e-mail & $\begin{array}{l}\text { Project } \\
\text { Manager }\end{array}$ & Project team \\
\hline Project Review & Monthly & Team meeting & $\begin{array}{c}\text { Project } \\
\text { Manager }\end{array}$ & Rashidya Manager \\
\hline Risk Mitigation Status & $\begin{array}{l}\text { As mitigation actions are } \\
\text { completed }\end{array}$ & $\begin{array}{l}\text { As mitigation actions are } \\
\text { completed }\end{array}$ & $\begin{array}{l}\text { As mitigation } \\
\text { actions are } \\
\text { completed }\end{array}$ & $\begin{array}{l}\text { As mitigation actions are } \\
\text { completed }\end{array}$ \\
\hline Requirement Changes & As changes are approved & Team meeting & $\begin{array}{l}\text { Project } \\
\text { manager }\end{array}$ & $\begin{array}{c}\text { Affected } \\
\text { ProjectParticipants }\end{array}$ \\
\hline Customer proposal review & Monthly & Phone & $\begin{array}{l}\text { Project } \\
\text { manager }\end{array}$ & Project team \\
\hline $\begin{array}{l}\text { Unpredictably requirement } \\
\text { Or specific fault }\end{array}$ & As needed & Team meeting & $\begin{array}{l}\text { Depend on } \\
\text { that situation }\end{array}$ & Project team \\
\hline
\end{tabular}



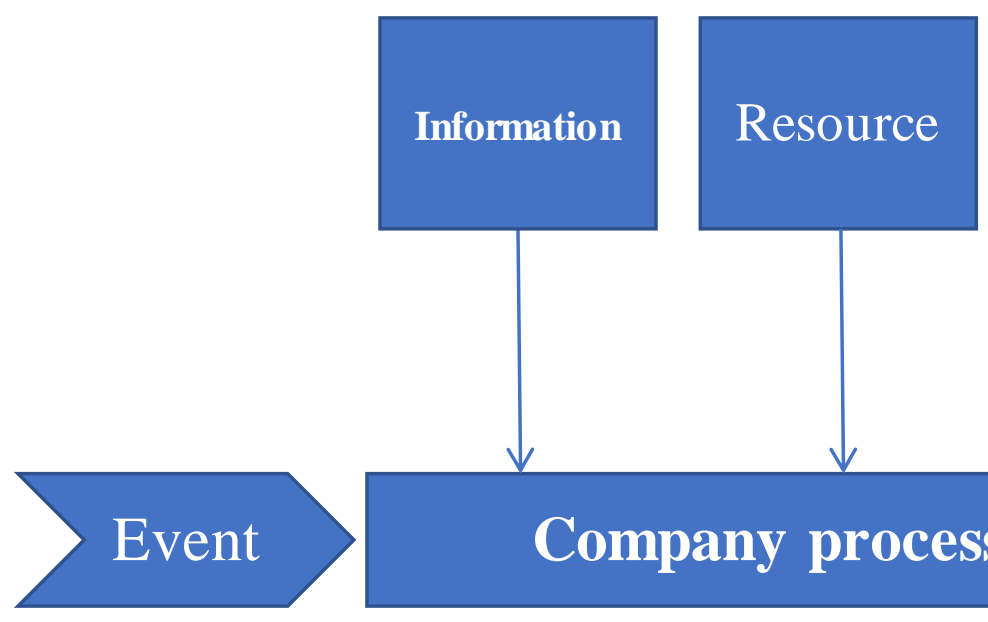

\section{Company process}

Output

\subsection{UML Process model}

- information :may include customer requirement, staff proposal or any requirement change

-Resource : all items and products that selling and buying between main and its branches

-Event: any risk or event under estimation or unpredictably occur .

-Goal : provide service and customer satisfy and give an environment to get staffs happy . -output: solve and answer (information and event fields of this diagram ).

Table 4.2 The Main and branches PC specifications

\begin{tabular}{c|cccccc} 
PC & CPU & RAM & Hard & OS & Model & Location \\
\hline Desktop & core i3 & $4 \mathrm{~GB}$ & 1 TB & $\begin{array}{c}\text { Win7 32 bit } \\
\text { professional } \\
\text { Windows }\end{array}$ & HP 2130 & $\begin{array}{c}\text { For each } \\
\text { branches } \\
\text { Desktop }\end{array}$ \\
Core i7 & 8 GB & 1TB & $\begin{array}{c}\text { Main } \\
\text { Server2008 }\end{array}$ &
\end{tabular}




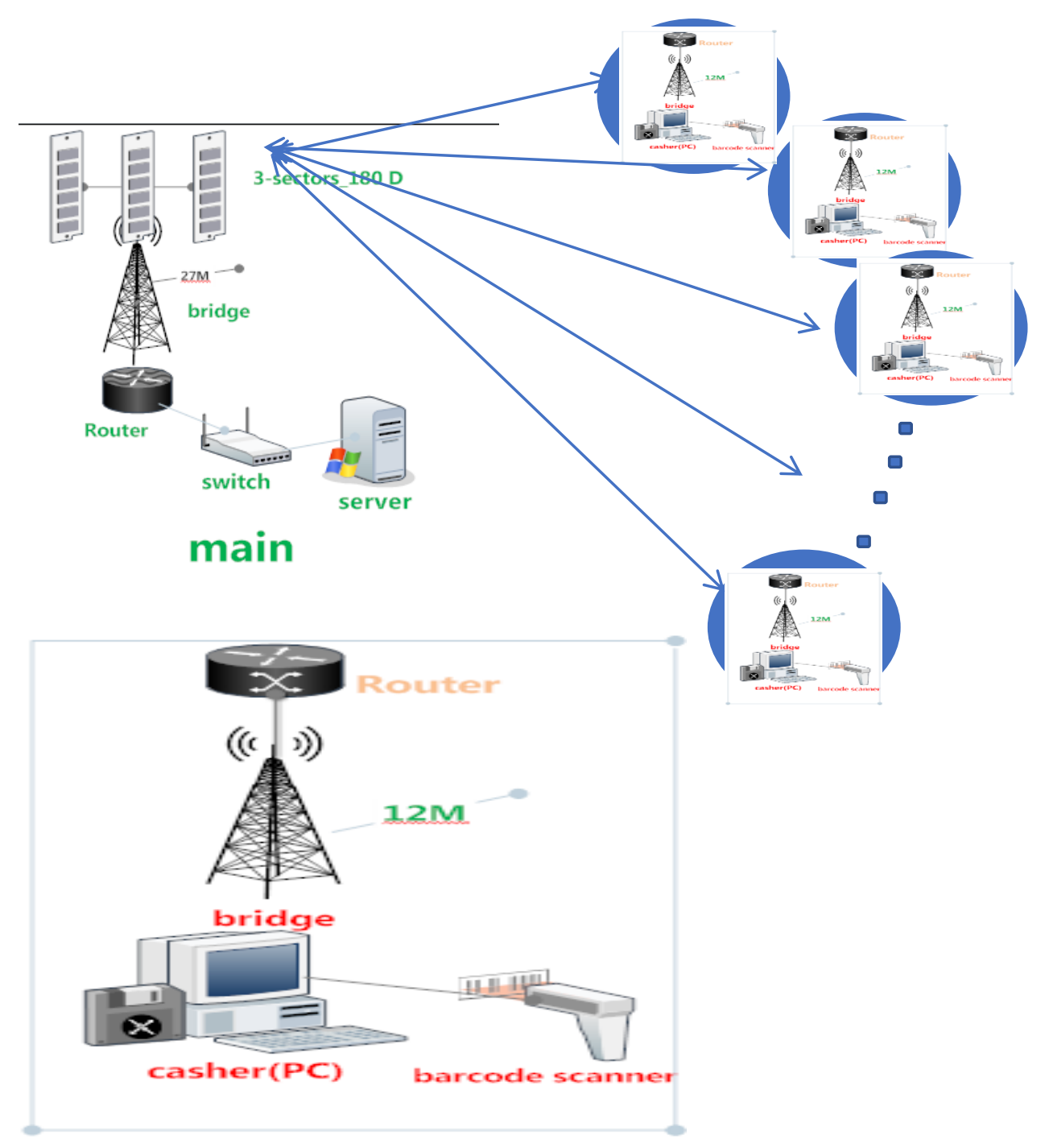

Char 4.2 Main Network diagram 


\section{Table 4.3 Documentations of project}

\begin{tabular}{|c|c|c|c|c|c|}
\hline Document & $\begin{array}{l}\text { Document } \\
\text { Template or } \\
\text { standard }\end{array}$ & $\begin{array}{c}\text { Created } \\
\text { By }\end{array}$ & $\begin{array}{c}\text { Reviewed } \\
\text { By }\end{array}$ & Target date & Distribution \\
\hline $\begin{array}{c}\text { Project } \\
\text { management } \\
\text { plan }\end{array}$ & Template & $\begin{array}{l}\text { Project } \\
\text { manager }\end{array}$ & Leaders & 12 Nov 2018 & $\begin{array}{l}\text { Rashidya } \\
\text { Company }\end{array}$ \\
\hline $\begin{array}{c}\text { Software } \\
\text { Requirements } \\
\text { Specification }\end{array}$ & Template & $\begin{array}{c}\text { Software } \\
\text { Leader }\end{array}$ & $\begin{array}{c}\text { Project } \\
\text { management }\end{array}$ & 12 Nov 2018 & $\begin{array}{l}\text { Rashidya } \\
\text { Company }\end{array}$ \\
\hline $\begin{array}{l}\text { Software Design } \\
\text { Specification }\end{array}$ & Template & $\begin{array}{c}\text { Software } \\
\text { Leader }\end{array}$ & $\begin{array}{c}\text { Project } \\
\text { management }\end{array}$ & 12 Nov 2018 & $\begin{array}{l}\text { Rashidya } \\
\text { Company }\end{array}$ \\
\hline $\begin{array}{l}\text { Network } \\
\text { Installation }\end{array}$ & Standard & $\begin{array}{l}\text { Hardware } \\
\text { leader }\end{array}$ & $\begin{array}{c}\text { Project } \\
\text { management }\end{array}$ & 12 Nov 2018 & $\begin{array}{l}\text { Rashidya } \\
\text { Company }\end{array}$ \\
\hline $\begin{array}{c}\text { Testing } \\
\text { Documentation }\end{array}$ & Standard & Test leader & $\begin{array}{c}\text { Project } \\
\text { management }\end{array}$ & 12 Nov 2018 & $\begin{array}{l}\text { Rashidya } \\
\text { Company }\end{array}$ \\
\hline Staff training & Standard & Staff leader & $\begin{array}{c}\text { Project } \\
\text { management }\end{array}$ & 12 Nov 2018 & $\begin{array}{l}\text { Rashidya } \\
\text { Company }\end{array}$ \\
\hline Final report & Standard & $\begin{array}{l}\text { Project } \\
\text { manager }\end{array}$ & $\begin{array}{c}\text { Project } \\
\text { management }\end{array}$ & 12 Nov 2018 & $\begin{array}{l}\text { Rashidya } \\
\text { Company }\end{array}$ \\
\hline
\end{tabular}

Table 5.1 project budget detail

\begin{tabular}{c|ccc}
\multicolumn{1}{c}{ Item } & Quantity & \multicolumn{2}{c}{ Price } \\
\hline Server & 1 & $450 \$$ & $12000 \$$ \\
Sector & 3 & $500 \$$ & 6000 \\
Barcode reader & 12 & \multicolumn{2}{c}{$100 \$$} \\
Hub-3com & 1 & $45 \$$ & $540 \$$ \\
Label-reader & 12 & $700 \$$ & $8400 \$$ \\
PC & 12 & $200 \$$ & $400 \$$ \\
Cable full STP & 2 cartoon & $50 \$$ & $2500 \$$ \\
Bridge & 50 M & $150 \$$ & $1950 \$$ \\
Router & 13 & \multicolumn{2}{c}{$100 \$$} \\
Rj-45 & 1000 items & $30 \$$ & $360 \$$ \\
Anti-virus AVG 2013 & 12 & $10 \$$ & $120 \$$ \\
MS-windows 7 & 12 & \multicolumn{2}{c}{$15 \$$} \\
Windows server & 1 & \multicolumn{2}{c}{$100 \$$} \\
E-hard drive & 1 & \multicolumn{2}{c}{$1000 \$-3000 \$$} \\
Database & 1 & \multicolumn{2}{c}{$156935 \$$} \\
Training & 3 &
\end{tabular}




\section{Phase Approval Process}

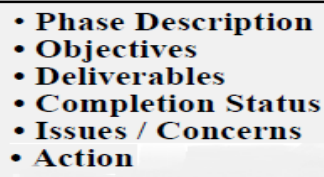

- Action

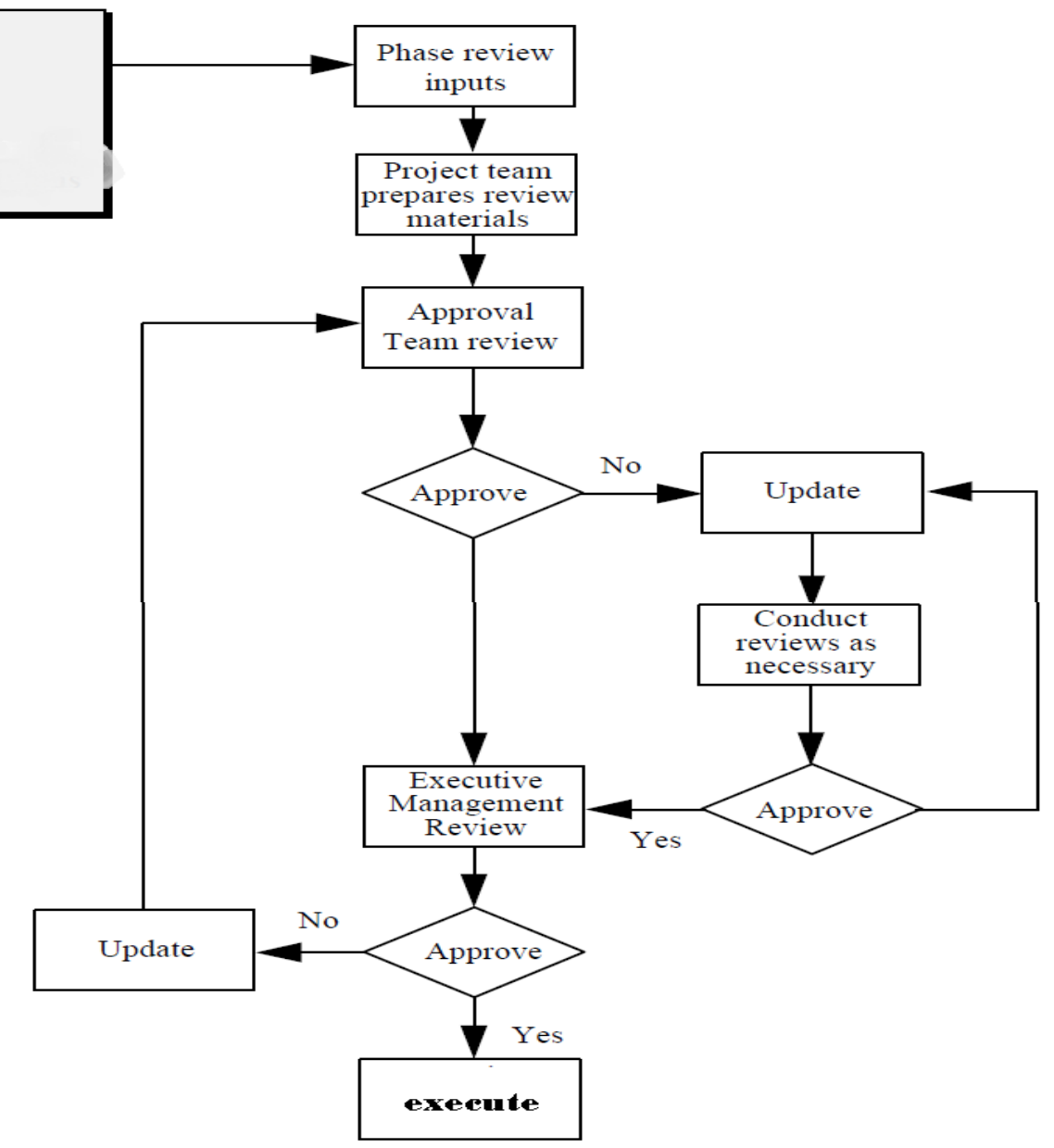

Figure 6.1 The project life cycle 